\title{
Differential effects on T-cell function following exposure to serum from schizophrenia smokers
}

M Herberth, DN Krzyszton, D Koethe, MR Craddock, E Bulger, E Schwarz, P Guest, FM Leweke and S Bahn

Molecular Psychiatry (2009) 14, 1145; doi:10.1038/mp.2008.137

Correction to: Molecular Psychiatry advance online publication 11 November 2008; doi: 10.1038/mp.2008.120

Following the online publication of the above article, the authors noted the following errors in Figure 1: the
$\mathrm{P}$ and $\mathrm{C}$ underneath the figure are interchanged. The $\mathrm{P}$ should be $\mathrm{C}$ and vice versa. The text is fine.

The authors apologize for any inconvenience caused.

\section{Developmental etiology for neuroanatomical and cognitive deficits in mice overexpressing Gas, a G-protein subunit genetically linked to schizophrenia}

MP Kelly, JM Stein, CG Vecsey, C Favilla, X Yang, SF Bizily, MF Esposito, G Wand, SJ Kanes and T Abel Molecular Psychiatry (2009) 14, 1145; doi:10.1038/mp.2008.138

Correction to: Molecular Psychiatry (2009) 14, 398-415; doi: $10.1038 / \mathrm{mp} .2008 .124$

Following the publication of the above article, the authors noted that the city and state indicated for the
University of Philadelphia was incorrect. The correct address is Philadelphia, PA.

\section{Functional polymorphisms in the interleukin-6 and serotonin transporter genes, and depression and fatigue induced by interferon- $\alpha$ and ribavirin treatment}

SJ Bull, P Huezo-Diaz, EB Binder, JF Cubells, G Ranjith, C Maddock, C Miyazaki, N Alexander, M Hotopf, AJ Cleare, S Norris, E Cassidy, KJ Aitchison, AH Miller and CM Pariante

Molecular Psychiatry (2009) 14, 1145; doi:10.1038/mp.2008.145

Correction to: Molecular Psychiatry (2009) 14, 1095-1104

(this issue); doi: 10.1038/mp.2008.48

Following the publication of the above article, the authors noted an error in the references. The first time reference 5 appears (page 2, line 4 in the 1st panel) referring to viral clearance rates it is used correctly, citing the paper by Schafer A et al. (2007). However, in all subsequent citations, reference 5 should instead refer to the following reference:

Reference

5 Kraus MR, Al Taie O, Schafer A, Pfersdorff M, Lesch KP, Scheurlen M. Serotonin-1A receptor gene HTR1A variation predicts interferoninduced depression in chronic hepatitis C. Gastroenterology 2007; 132: 1279-1286. 